\title{
BIOLOGICAL VALUE OF PROTEIN OF CULINARY PRODUCTS BASED ON MILK-PROTEIN CONCENTRATE
}

\author{
Grygorii Deinychenko \\ Department of Processes and Equipment of Food and Hospitality-Restaurant Industry \\ named after M. Belyaev ${ }^{1}$ \\ deinychenkogv@ukr.net \\ Inna Zolotukhina \\ Department of Processes and Equipment of Food and Hospitality-Restaurant Industry \\ named after M. Belyaev ${ }^{1}$ \\ zolotce5@gmail.com \\ Viktoriia Skrynnik \\ Department of Hotel, Restaurant Business and Tourism ${ }^{1}$ \\ v_fedak@ukr.net \\ Liudmyla Deinychenko \\ Department of Technology of Restaurant and Ayurvedic Products \\ National University of Food Technologies \\ 68 Volodymirska, str., Kyiv, Ukraine, 01601 \\ deliugri@gmail.com \\ Tamara Kravchenko \\ Department of Vocational Education and Technologies according to the Profiles \\ Uman State Pedagogical University named after Pavlo Tychyna \\ 2 Sadova str., Uman, Ukraine, 20300 \\ tamara.kravchenko2019@gmail.com \\ ${ }^{1}$ Kharkiv State University of Food Technology and Trade \\ 333 Klochkovska str., Kharkiv, Ukraine, 61051
}

\begin{abstract}
The aim of this work is to determine the usage effectiveness of milk-protein concentrates as an analogue of cottage cheese at culinary products manufacturing. For attaining the set aim, we determined the biological value of protein in products, made using a milk-protein concentrate, comparing to traditional culinary products of fatless cottage cheese.

The research object was chosen as a milk-protein concentrate of buttermilk, obtained by the method of thermo-acid coagulation. Puree of cranberries was used as a coagulant. Classic recipes of different groups of culinary products, based on cottage cheese: cheese cakes, cottage cheese casserole, cottage cheese stuffing and cottage cheese biscuits were used as control samples for the studies.

The protein value of the milk concentrate and also products on its base was determined by the method of digestible indispensable amino acid score calculation.

The conducted studies have demonstrated that despite the less amino acid score of the concentrate, comparing with a control sample, products on its base have higher amino acid score, comparing with their cottage cheese analogues. Thus, the amino acid score of cheese cakes based on the concentrate is $84 \%$ and exceeds the control sample, which amino acid score is $33 \%$, in 2.5 times. The amino acid score of cottage cheese casserole based on the concentrate is $68 \%$ and exceeds the control sample in 1.7 times. The amino acid score parameter of protein stuffing is $94 \%$ that exceeds the control sample with score $36 \%$ in 2.6 times. The amino acid score of biscuits based on the concentrate is $26 \%$ that exceeds the score of a cottage cheese analogue in 2 times.

The obtained results may be used for elaborating and correcting the food ration for the population under conditions of protein deficiency.

Keywords: milk-protein concentrate, fatless cottage cheese, cranberry, amino acid score, digestible indispensable amino acid score.
\end{abstract}




\section{Introduction}

One of most important tasks in the sphere of health protection for today is to fight against alimentary diseases that are ones, appeared as a result of defective or insufficient nutrition. Such diseases result in an increased number of different illnesses, precocious exhaustion of the organism, deceleration of the physical and psychological development and as a result, mortality rate growth.

One of most spread alimentary diseases for today is protein deficiency. It is known, that for the last years the average per capita index of protein consumption decreased by $17 . .22 \%$, and amount of consumed protein in families with a low income level doesn't exceed $40 \mathrm{~g}$ per day [1-3].

It is possible to improve the food status of the population by including foods, containing an essential amount of protein, in the food ration. In particular, we talk about products, made with protein concentrates and isolates, which number at the world market of ingredients and food supplements continuously grows [4]. Among the last ones, we must specially note milk-protein concentrates, obtained by processing protein-carbohydrate milk raw materials: whey, buttermilk and skim milk. Milk protein is characterized by the high digestibility and biological value and also low cost price [5]. These characteristics determine the use of milk-protein concentrates (MPC) in food products technologies for increasing the level of protein products consumption, even in countries with a low level of population's incomes.

The essential part in the total volume of food products is culinary products and dishes of cottage cheese, characterized with a high labor-intensity and many stages of technological processes that predetermine a little assortment of such products [6]. This problem is especially noticeable on the example of restaurant economy institutions, which services are used by more and more number of people under conditions of urbanization and continuous growth of an urban share of the population.

The above information allows to state that for satisfying the growing demand in food products of cottage cheese, it is rational to use MPC as one of main ingredients. It results in increasing the share of protein substances in the food ration and in widening the assortment of cottage cheese dishes and culinary products.

But it must be noted, that despite the high content of protein substances, many MPC are characterized with their worse digestibility, comparing with such traditional product as cottage cheese. This fact may doubt the theory about the effectiveness of using MPC as a substitute of cottage cheese at culinary products manufacturing.

So, the aim of this study is to determine the biological value of protein in products, made using the milk-protein concentrate of cranberry puree, comparing with traditional products of cottage cheese.

\section{Materials and Methods}

The research object was chosen as MPC of buttermilk, obtained by the method of thermo-acid coagulation after buttermilk pasteurization at temperature $90 \ldots 95^{\circ} \mathrm{C}$ during $14 \ldots 15 \mathrm{~min}$. Cranberry puree (MPCC) was used as a coagulant [7]. Fatless cottage cheese, obtained by milk pasteurization at temperature $78 \ldots 80^{\circ} \mathrm{C}$ during $20 \ldots 30 \mathrm{~s}$, with further souring of a cottage cheese clot at temperature $28 \ldots 32^{\circ} \mathrm{C}$, was used as a control sample.

The classic recipe of cheese cakes was used as a base and control sample for conducting the studies [8]. For preparing them, fatless cottage cheese was mixed with egg mass, sugar and sifted wheat flour for getting dough and further forming the products. The modified recipe of "Protein cheese cakes" contains MPCC as an analogue of fatless cottage cheese, as well as less amount of sugar that is explained by taste qualities of the used MPC [9].

The recipes of cottage cheese casserole, stuffing and biscuits were modified analogously $[8,10]$.

The amino acid composition of MPCC and fatless cottage cheese was determined by the chromatographic method at laboratories of the Institute of food resources of NAAS of Ukraine. The liquid-based chromatograph Shimadzu LC-2010 (Japan) was used for conducting the analyses. The amino acid composition of products based on fatless cottage cheese and MPCC was determined by the calculation method [11]. 
The biological value of MPCC protein and products on its base was determined by the digestible indispensable amino acid score (DIAAS) method of calculation [12]. Coefficients of ileal digestibility of amino acids were taken according to the report of the consulting subcommittee of FAO, 2011 about quality assessment of protein in human nutrition [13]. The recommended levels of amino acids consumption were accepted according to the standards for the age group "children, older 3 years, teenagers and adults", presented by the WHO FAO experts' report of "Quality assessment of food protein in human nutrition" [12].

\section{1. Experimental procedures}

At the first stage of the research there was determined the biological value of MPCC protein, comparing with one of fatless cottage cheese.

The digestible content of indispensable amino acids (IAA) in the product was calculated by the formula:

Digestible concentration of IAA $=$ Content of IAA in $1 \mathrm{~g}$ of protein of the product $\times$ $\times$ true ileal IAA digestibility.

The digestible IAA reference ratio was calculated by the formula:

Digestible IAA reference ratio=

$=$ True ileal digestible IAA content/IAA reference pattern.

For calculating the digestible indispensable amino acid score, the lowest value of IAA digestibility coefficient, multiplied by $100 \%$ was used, with further indication of the limiting amino acid. All this must be related to the research methods.

The research results are presented in Tables $\mathbf{1 , 2}$.

Table 1

Calculation of digestible indispensable amino acid score for fatless cottage cheese

\begin{tabular}{|c|c|c|c|c|c|c|c|}
\hline IAA & $\begin{array}{c}\text { Product } \\
\text { weight, g }\end{array}$ & $\begin{array}{l}\text { Protein con- } \\
\text { tent in } 100 \mathrm{~g} \\
\text { of product }\end{array}$ & $\begin{array}{l}\text { IAA content in } \\
1 \mathrm{~g} \text { of protein } \\
\text { of the product }\end{array}$ & $\begin{array}{c}\text { True ileal } \\
\text { IAA digest- } \\
\text { ibility }\end{array}$ & $\begin{array}{l}\text { True ileal di- } \\
\text { gestible IAA } \\
\text { content }\end{array}$ & $\begin{array}{l}\text { IAA refer- } \\
\text { ence pattern }\end{array}$ & $\begin{array}{l}\text { Digestible } \\
\text { IAA refer- } \\
\text { ence ratio }\end{array}$ \\
\hline & 100 & 18 & - & - & - & - & - \\
\hline Isoleucine & - & - & 55.6 & 0.96 & 53.4 & 30 & 1.78 \\
\hline Leucine & - & - & 102.8 & 0.97 & 99.7 & 61 & 1.63 \\
\hline Methionine + cystine & - & - & 32.2 & 0.97 & 31.2 & 23 & 1.36 \\
\hline Lysine & - & - & 80.6 & 0.97 & 78.2 & 48 & 1.63 \\
\hline $\begin{array}{c}\text { Phenylalanine }+ \\
\text { tyrosine }\end{array}$ & - & - & 103.3 & 0.98 & 101.2 & 41 & 2.46 \\
\hline Threonine & - & - & 44.4 & 0.92 & 40.8 & 25 & 1.63 \\
\hline Tryptophan & - & - & 10.0 & 0.97 & 9.7 & 6.6 & 1.47 \\
\hline Valine & - & - & 55.0 & 0.95 & 52.3 & 40 & 1.31 \\
\hline DIASS, \% & \multicolumn{7}{|c|}{$131 \%$ (by valine) } \\
\hline
\end{tabular}

At the second stage of the studies there was assessed the biological value of protein of culinary products made using MPCC, comparing with their analogues, based on fatless cheese. DIAAS value for classic cottage cheese cakes and "Protein cheese cakes" was calculated by the method, elaborated for assessing the protein quality of multicomponent food products [12]. The research results are presented in Tables 3-5. DIAAS value for other culinary products, based on MPCC, comparing with their control analogues, were calculated analogously (Table 5). 
Table 2

Calculation of digestible indispensable amino acid score for MPCC

\begin{tabular}{|c|c|c|c|c|c|c|c|}
\hline IAA & $\begin{array}{c}\text { Product } \\
\text { weight, g }\end{array}$ & $\begin{array}{l}\text { Protein con- } \\
\text { tent in } 100 \mathrm{~g} \\
\text { of product }\end{array}$ & $\begin{array}{l}\text { IAA content in } \\
1 \mathrm{~g} \text { of protein of } \\
\text { the product }\end{array}$ & $\begin{array}{c}\text { True ileal } \\
\text { IAA digest- } \\
\text { ibility }\end{array}$ & $\begin{array}{l}\text { True ileal di- } \\
\text { gestible IAA } \\
\text { content }\end{array}$ & $\begin{array}{l}\text { IAA refer- } \\
\text { ence pattern }\end{array}$ & $\begin{array}{l}\text { Digestible IAA } \\
\text { reference ratio }\end{array}$ \\
\hline & 100 & 30.4 & - & - & - & - & - \\
\hline Isoleucine & - & - & 42.8 & 0.9 & 38.5 & 30 & 1.4 \\
\hline Leucine & - & - & 83.0 & 0.92 & 76.4 & 61 & 1.19 \\
\hline Methionine + cystine & - & - & 39.5 & 0.87 & 34.4 & 23 & 1.74 \\
\hline Lysine & - & - & 61.0 & 0.93 & 56.7 & 48 & 1.13 \\
\hline $\begin{array}{c}\text { Phenylalanine }+ \\
\text { tyrosine }\end{array}$ & - & - & 70.5 & 0.91 & 64.2 & 41 & 1.51 \\
\hline Threonine & - & - & 44.9 & 0.84 & 37.7 & 25 & 1.52 \\
\hline Tryptophan & - & - & 10.9 & 0.89 & 9.7 & 6.6 & 1.42 \\
\hline Valine & - & - & 62.3 & 0.89 & 55.5 & 40 & 1.14 \\
\hline DIASS, \% & \multicolumn{7}{|c|}{$118 \%$ (by lysine) } \\
\hline
\end{tabular}

Table 3

Calculation of digestible indispensable amino acid score for cheese cakes based on fatless cottage cheese

\begin{tabular}{|c|c|c|c|c|c|c|c|c|c|c|c|c|c|}
\hline \multirow[b]{2}{*}{ Parameter } & \multicolumn{4}{|c|}{ Nutrients content, mg } & \multicolumn{3}{|c|}{$\begin{array}{c}\text { True ileal IAA digest- } \\
\text { ibility }\end{array}$} & \multicolumn{3}{|c|}{$\begin{array}{l}\text { True ileal digestible } \\
\text { IAA content }\end{array}$} & \multirow{2}{*}{ 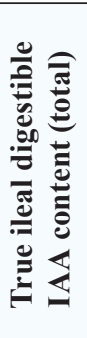 } & \multirow{2}{*}{ 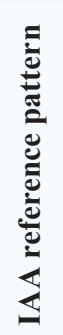 } & \multirow{2}{*}{ 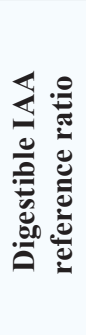 } \\
\hline & ڤે & 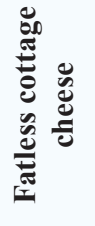 & 离 & $\begin{array}{l}6 \\
600 \\
601 \\
010\end{array}$ & 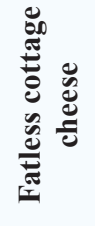 & 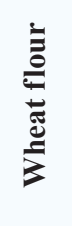 & $\begin{array}{l}\mathscr{6} \\
600 \\
60 \\
60\end{array}$ & 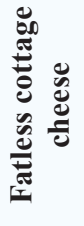 & 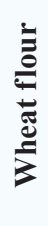 & 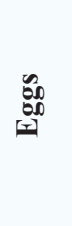 & & & \\
\hline $\begin{array}{l}\text { Recipe components } \\
\text { weight, } g\end{array}$ & 100 & 80 & 12 & 3 & - & - & - & - & - & - & - & - & - \\
\hline $\begin{array}{l}\text { Protein content } \\
\text { in } 100 \mathrm{~g} \text { of raw } \\
\text { materials }\end{array}$ & - & 18 & 10.3 & 12.7 & - & - & - & - & - & - & - & - & - \\
\hline $\begin{array}{l}\text { Protein content in } \\
100 \mathrm{~g} \text { of culinary } \\
\text { products, } \mathrm{g}\end{array}$ & 16.02 & 14.40 & 1.24 & 0.38 & - & - & - & - & - & - & - & - & - \\
\hline \multicolumn{14}{|c|}{ IAA } \\
\hline Isoleucine & - & 56 & 35 & 47 & 0.96 & 0.9 & 0.91 & 769 & 39 & 16 & 13 & 30 & 0.44 \\
\hline Leucine & - & 103 & 69 & 87 & 0.97 & 0.91 & 0.91 & 1436 & 78 & 30 & 25 & 61 & 0.41 \\
\hline $\begin{array}{l}\text { Methionine }+ \\
\text { cystine }\end{array}$ & - & 32 & 39 & 61 & 0.97 & 0.9 & 0.91 & 450 & 43 & 21 & 8 & 23 & 0.36 \\
\hline Lysine & - & 81 & 22 & 71 & 0.97 & 0.87 & 0.91 & 1126 & 24 & 25 & 19 & 48 & 0.39 \\
\hline $\begin{array}{l}\text { Phenylalanine }+ \\
\text { tyrosine }\end{array}$ & - & 103 & 81 & 87 & 0.98 & 0.89 & 0.91 & 1458 & 89 & 30 & 25 & 41 & 0.62 \\
\hline Threonine & - & 44 & 29 & 48 & 0.92 & 0.86 & 0.91 & 588 & 31 & 17 & 10 & 25 & 0.41 \\
\hline Tryptophan & - & 10 & 13 & 16 & 0.97 & 0.89 & 0.91 & 140 & 14 & 5 & 3 & 6.6 & 0.39 \\
\hline Valine & - & 56 & 41 & 61 & 0.95 & 0.9 & 0.91 & 759 & 45 & 21 & 13 & 40 & 0.33 \\
\hline DIASS, \% & \multicolumn{13}{|c|}{33 (by valine) } \\
\hline
\end{tabular}


Table 4

Calculation of digestible indispensable amino acid score for "Protein cheese cakes"

\begin{tabular}{|c|c|c|c|c|c|c|c|c|c|c|c|c|c|}
\hline \multirow[b]{2}{*}{ Parameter } & \multicolumn{4}{|c|}{ Nutrients content, mg } & \multicolumn{3}{|c|}{$\begin{array}{c}\text { True ileal IAA digest- } \\
\text { ibility }\end{array}$} & \multicolumn{3}{|c|}{$\begin{array}{l}\text { True ileal digestible } \\
\text { IAA content }\end{array}$} & \multirow{2}{*}{ 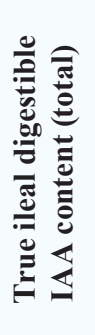 } & \multirow{2}{*}{ 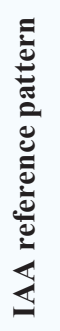 } & \multirow{2}{*}{ 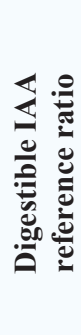 } \\
\hline & 离 & $\begin{array}{l}u \\
\text { U } \\
\sum\end{array}$ & 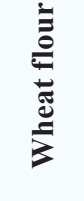 & $\begin{array}{l}6 \\
600 \\
600 \\
0=1\end{array}$ & 己 & 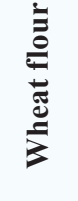 & $\begin{array}{l}\mathscr{6} \\
600 \\
601\end{array}$ & $\begin{array}{l}U \\
己 \\
\sum\end{array}$ & & $\begin{array}{l}0.00 \\
600 \\
601\end{array}$ & & & \\
\hline $\begin{array}{l}\text { Recipe components } \\
\text { weight, g }\end{array}$ & 100 & 84 & 10.7 & 2.7 & - & - & - & - & - & - & - & - & - \\
\hline $\begin{array}{l}\text { Protein content } \\
\text { in } 100 \mathrm{~g} \text { of raw } \\
\text { materials }\end{array}$ & - & 30.4 & 10.3 & 12.7 & - & - & - & - & - & - & - & - & - \\
\hline $\begin{array}{l}\text { Protein content in } \\
100 \mathrm{~g} \text { of culinary } \\
\text { products, } \mathrm{g}\end{array}$ & 26.98 & 25.54 & 1.10 & 0.34 & - & - & - & - & - & - & - & - & - \\
\hline \multicolumn{14}{|c|}{ IAA } \\
\hline Isoleucine & - & 43 & 35 & 47 & 0.9 & 0.9 & 0.91 & 984 & 35 & 15 & 28 & 30 & 0.93 \\
\hline Leucine & - & 83 & 69 & 87 & 0.92 & 0.91 & 0.91 & 1950 & 69 & 27 & 55 & 61 & 0.91 \\
\hline $\begin{array}{l}\text { Methionine }+ \\
\text { cystine }\end{array}$ & - & 40 & 39 & 61 & 0.87 & 0.9 & 0.91 & 878 & 39 & 19 & 25 & 23 & 1.10 \\
\hline Lysine & - & 61 & 22 & 71 & 0.93 & 0.87 & 0.91 & 1449 & 21 & 22 & 40 & 48 & 0.84 \\
\hline $\begin{array}{l}\text { Phenylalanine }+ \\
\text { tyrosine }\end{array}$ & - & 71 & 81 & 87 & 0.91 & 0.89 & 0.91 & 1638 & 79 & 27 & 47 & 41 & 1.15 \\
\hline Threonine & - & 45 & 29 & 48 & 0.84 & 0.86 & 0.91 & 963 & 27 & 15 & 27 & 25 & 1.09 \\
\hline Tryptophan & - & 11 & 13 & 16 & 0.89 & 0.89 & 0.91 & 248 & 12 & 5 & 7 & 6.6 & 1.08 \\
\hline Valine & - & 62 & 41 & 61 & 0.89 & 0.9 & 0.91 & 1416 & 40 & 19 & 40 & 40 & 1.00 \\
\hline DIASS, \% & \multicolumn{13}{|c|}{84 (by lysine) } \\
\hline
\end{tabular}

Table 5

Digestible indispensable amino acid score of culinary products, based on MPCC comparing with control samples

\begin{tabular}{cl}
\hline Culinary product & DIASS, \% \\
\hline Cottage cheese casserole (control) & 39 (by valine) \\
Milk-protein casserole & 68 (by lysine) \\
Cottage cheese stuffing (control) & 36 (by valine) \\
Milk-protein stuffing & 94 (by lysine) \\
Cottage cheese biscuit (control) & 13 (by lysine) \\
Milk-protein biscuit & 26 (by lysine)
\end{tabular}

\section{Results}

As it can be seen from the data, presented in table 1 and 2 , the amount of protein in $100 \mathrm{~g}$ of MPCC is $30.4 \mathrm{~g}$ that exceeds the analogous index of the control sample by $68 \%$. But the amount of IAA in MPC is by $14 \%$ less, that is $414.9 \mathrm{mg}$ for $1 \mathrm{~g}$ of MPCC against $483.9 \mathrm{~g}$ for $1 \mathrm{~g}$ of protein for fatless cottage cheese.

The amount of sulfur-bearing amino acids (methionine and cystine), stabilizing the protein structure, acting as detoxicants and necessary for biosynthesis of adrenalin, choline and other sub- 
stances, in MPCC is by $23 \%$ higher than the analogous index for the control sample. At that it must be noted, that the content of aromatic amino acids (phenylalanine, tyrosine and tryptophan), having an extreme importance for the human nervous system functioning as an element, necessary for biosynthesis of neurotransmitters, is by $28 \%$ less for MPCC, comparing with the control sample. The concentration of amino acids with the double bond (isoleucine, leucine, valine) also decreases for MPCC by $12 \%$.

It must be also noted, that the true ileal IAA digestibility for MPCC is in average 0.89 that is by $7 \%$ less that the analogous index for fatless cottage cheese (0.96).

The conducted calculation of digestible IAA score (DIAAS) has demonstrated that the amino acid score of MPCC protein is by $13 \%$ less than the one of fatless cottage cheese. At that the limiting amino acid for MPCC is lysine, whereas the amino acid score of the control sample is limited by valine.

From our point of view the abovementioned data are explained by the technological conditions of MPCC production. Thus, the temperature increase of buttermilk pasteurization from $78 \ldots 80{ }^{\circ} \mathrm{C}$ to $90 \ldots 95^{\circ} \mathrm{C}$ can be explained by hidden denaturation of whey proteins and their loss of native conformation that allow essentially raise the amount of protein substances in an obtained clot. At the same time the significant increase of pasteurization time (from $20 \ldots 30 \mathrm{~s}$ to $14 \ldots 15 \mathrm{~min}$ ) results in the fact that sulfhydryl groups $(-\mathrm{SH})$ and hydrophobic parts of the polypeptide chain become more accessible. As a result of it, intermolecular disulfite (-S-S-) bridges and high-molecular compounds form [14] that, in their turn, are negatively reflected on the digestibility of the obtained MPC.

The analysis of the data of tables 3...5 demonstrates that despite the less DIAAS of MPCC, comparing with the control sample, the products based on MPC have the higher amino acid score, comparing with their cottage cheese analogues. Thus, DIAAS of "Protein cheese cakes" exceeds the control in 2.5 times, "Milk-protein casserole"- in 1.7 times, "Milk-protein stuffing"- in 2.6 times, "Milk-protein biscuit" - in 2 times. Such digestibility increase of the culinary products based on MPCC, is explained by the essential increase of the total protein mass in the ready products composition.

At that it must be noticed, that for all culinary products based on MPCC, the limiting amino acid is lysine as well as for MPCC itself. Analogously, valine is the limiting amino acid for the most part of culinary products based on fatless cottage cheese. This regularity is explained by the superior content of cottage cheese or MPCC, comparing with other components, included in the recipe of the proposed culinary products.

\section{Conclusions}

Based on the conducted study, there has been proved the effectiveness of MPC usage as a substitute of cottage cheese at culinary products making.

The conducted studies have demonstrated that despite the less DIAAS of MPCC, comparing with the control sample, the products, based on MPC, have the higher amino acid score comparing with their cottage cheese analogues. Thus, DIAAS of cheese cakes based on MPCC exceeds the control in 2.5 times, the one of casserole - in 1.7 times, stuffing - in 2.6 times, biscuit - in 2 times.

The conducted studies have a series of advantages and shortcomings. Thus, the presented data confirm the high effectiveness of MPC usage in technologies of cottage cheese products, even under conditions of worse digestibility of separate components, comparing with traditional cottage cheese. At the same time the analysis of DIAAS has been conducted for the different culinary products (fried and baked culinary products, stuffing for semi-finished products, floury confectionary products and so on). It allows to state, that MCP use as a substitute of cottage cheese for different groups of food products is equally effective.

At the same time for getting more information, it is rational to study DIAAS of culinary products, based on MPC, obtained by other technologies, for example, thermo-calcium coagulation or membrane methods. The fact that the obtained data describe the regularities, typical to culinary products, based on milk raw material concentrates, may be also considered a shortcoming. The presented results may be inadequate for products, prepared using protein concentrates of other raw materials (egg, soya, ones of cereals and so on). 
The obtained data may be used in many fields, connected with food products manufacturing. Thus, it is recommended to implement the elaborated technologies in enterprises of restaurant industry for widening the assortment of products. It is especially urgent to implement such products at food industry enterprises for correcting the food ration of the population under conditions of protein deficiency. The regularities, presented in the work, may be also used by nutritionists for calculating food rations for children, sportsmen and other population groups, whose nutrition needs increasing the protein consumption level. Physiologists may use them for assessing the level of organism provision with protein substances.

This work is a continuation of the earlier conducted studies on assessment of the food and biological value of MPCC and products on their base [7, 9].

\section{References}

[1] Tomé, D., Chaumontet, C., Even, P. C., Darcel, N., Azzout-Marniche, D. (2019). Protein status modulates the rewarding value of foods and meals to maintain an adequate protein intake. Physiology \& Behavior, 206, 7-12. doi: https://oi.org/10.1016/ j.physbeh.2019.03.012

[2] Tilly, J. (2017). Opportunities to Improve Nutrition for Older Adults and Reduce Risk of Poor Health Outcomes. Administration for Community Living or the U.S. Department of Health and Human Services. Avaliable at: http://nutritionandaging.org/ wp-content/uploads/2017/03/Malnutrition-Issue-Brief-final-3-2017.pdf

[3] Izadi, A., Khedmat, L., Mojtahedi, S. Y. (2019). Nutritional and therapeutic perspectives of camel milk and its protein hydrolysates: A review on versatile biofunctional properties. Journal of Functional Foods, 60, 103441. doi: https://oi.org/10.1016/ j.jff.2019.103441

[4] Aydar, E. F., Tutuncu, S., Ozcelik, B. (2020). Plant-based milk substitutes: Bioactive compounds, conventional and novel processes, bioavailability studies, and health effects. Journal of Functional Foods, 70, 103975. doi: https://oi.org/10.1016/ j.jff.2020.103975

[5] Agarwal, A., Pathera, A. K., Kaushik, R., Kumar, N., Dhull, S. B., Arora, S., Chawla, P. (2020). Succinylation of milk proteins: Influence on micronutrient binding and functional indices. Trends in Food Science \& Technology, 97, 254-264. doi: https:// doi.org/10.1016/j.tifs.2020.01.016

[6] Caleja, C., Ribeiro, A., Barros, L., Barreira, J. C. M., Antonio, A. L., Oliveira, M. B. P. P. et. al. (2016). Cottage cheeses functionalized with fennel and chamomile extracts: Comparative performance between free and microencapsulated forms. Food Chemistry, 199, 720-726. doi: https://doi.org/10.1016/j.foodchem.2015.12.085

[7] Gnitsevych, V., Yudina, T., Deinychenko, L. (2016). Technology of milk-protein co-precipitates and their biological value. Commodities and Markets, 2, 148-157.

[8] Sbornik retseptur blyud i kulinarnyh izdeliy dlya predpriyatiy obshchestvennogo pitaniya (1982). Moscow, 720.

[9] Gnitsevych, V., Yudina, T., Deinychenko, L. (2017). Technology and biological value of products from milk-protein concentrate. Commodities and Markets, 1, 139-148.

[10] Bondar, O. V., Dovha, O. O., Stukalska, N. M. et. al. (2015). Zbirnyk retseptur kulinarnoi produktsiyi i napoiv (tekhnolohichnykh kart) dlia kharchuvannia ditei u doshkilnykh navchalnykh zakladakh. Kyiv: ArtEk, 715.

[11] Skurihin, I. S., Volgarev, M. N. (Eds.) (1987). Himicheskiy sostav pishchevyh produktov. Kn. 2: Spravochnye tablitsy soderzhaniya aminokislot, zhirnyh kislot, vitaminov, makro- i mikro- elementov, organicheskih kislot i uglevodov. Moscow: Agropromizdat, 360 .

[12] Dietary protein quality evaluation in human nutrition. Report of an FAO Expert Consultation. (2011). Auckland, New Zealand. Available at: http://www.fao.org/ag/humannutrition/35978-02317b979a686a57aa4593304ffc17f06.pdf

[13] Report of a Sub-Committee of the 2011 FAO Consultation on "Protein Quality Evaluation in Human Nutrition" on: The assessment of amino acid digestibility in foods for humans and including a collation of published ileal amino acid digestibility data for human foods. Available at: http://www.fao.org/ag/humannutrition/36216-04a2f02ec02eafd4f457dd2c9851b4c45.pdf

[14] Braudo, E. E. (1997). Funktsional'nye vzaimodeystviya v mnogokomponentnyh sistemah, soderzhashchih polisaharidy. Pishcha. Ekologiya. Chelovek: materialy vtoroy mezhdunarodnoy nauchno-tehnicheskoy konferentsii. Moscow, 60. 